\title{
Membrane-bound CD95 ligand expressed on human antigen-presenting cells prevents alloantigen-specific $T$ cell response without impairment of viral and third-party $\mathrm{T}$ cell immunity
}

\author{
G Strauss $^{1}$, W Osen ${ }^{2}$, I Knape ${ }^{1}$, E-M Jacobsen ${ }^{1}$, SM Müller ${ }^{3}$ and K-M Debatin ${ }^{\star, 1}$
}

Genetically modified antigen-presenting cells (APC) represent an attractive strategy for in vitro immunomodulation. In the human system, APC expressing HLA-A1 and a membrane-bound form of CD95L (m-CD95L) were used for selective depletion of HLA-A1specific $T$ cells. In short-term assays, $m$-CD95L-expressing APC-induced apoptosis in activated $T$ cells and the constitutive presence of $m-C D 95 L$ and HLA-A1 expressing APC in long-term T cell cultures prevented the expansion of CD4 ${ }^{+}$and CD8 ${ }^{+}$ HLA-A1-specifc T cells and the development of HLA-A1-specific cytotoxicity. However, immunity towards third party, viral and bacterial antigens was maintained and T cells spared from depletion could be induced to develop cytotoxicity towards unrelated antigens. Interestingly, inhibition of HLA-A1-specific T cell response absolutely requires the coexpression of m-CD95L and HLAA1 antigen on the same APC. Thus, $\mathrm{m}-\mathrm{CD} 95 \mathrm{~L}$ expressing APC might be used in clinical settings to obtain tolerance induction in allogeneic transplantation systems or autoimmune diseases.

Cell Death and Differentiation (2007) 14, 480-488. doi:10.1038/sj.cdd.4402019; published online 11 August 2006

\begin{abstract}
Apoptosis mediated by the CD95 system plays a pivotal regulatory role in the maintenance of immune homeostasis. Deficiency in CD95 or CD95L expression in T cells mediates lymphoproliferative disorders due to the lack of apoptosis induction. ${ }^{1}$ Paradoxically, several molecules of the CD95 signaling pathway are also required for $\mathrm{T}$ cell activation and proliferation. ${ }^{2}$ In addition to T cells, live and death of antigenpresenting cells, which initiate $T$ cell responses has to be tightly controlled to avoid the establishment of autoimmunity. ${ }^{3}$ Activation-induced cell death (AICD) represents an apoptosis mechanism mediated via the interaction of CD95 with its ligand CD95L, to mediate $T$ cell death and initiate the termination of an immune response to maintain tolerance to self antigens and to prevent autoimmunity. ${ }^{4}$ Owing to the constitutive expression of CD95L in immune privileged organs such as testis or eye, ${ }^{5,6}$ CD95L was considered as an immunoprotective agent able to counterattack activated $T$ cells in vivo. However, the role of CD95L in transplantation tolerance is still controversial. While allogeneic pancreatic islands transplanted together with syngeneic CD95L expressing myoblasts were tolerated, ${ }^{7}$ allogeneic CD95L expressing pancreatic $\beta$ cells were rejected due to increased neutrophil infiltration. ${ }^{8}$ Lack of immunogenicity of tumors and resistance towards $T$ cell attacks were also correlated with the expression of CD95L on tumor tissues. Such tumors were shown to
\end{abstract}

kill CD95-positive cells in vitro. ${ }^{9}$ However, transfection of CD95L into murine tumor cells did not enhance tumor growth, but instead induced accelerated tumor rejection by neutrophils in vivo. ${ }^{10-12}$

Systemic immunomodulation by CD95L was successfully achieved by antigen-presenting cells modified to express CD95L. ${ }^{13}$ In mice antigen-specific elimination of activated T cells by engagement of CD95L on APC and CD95 on the activated $T$ cells has been demonstrated in several models. ${ }^{14,15}$ This approach benefits from the high specificity since only T cells responding to the antigen expressed on the APC are deleted by CD95/CD95L interaction while the remaining $\mathrm{T}$ cells are still responsive to unrelated antigens. However, successful elimination of antigen-specific T cells via the CD95 system depends on the CD95-sensitivity of T cells. As human naïve $T$ cells are resistant to CD95-mediated apoptosis and acquire CD95-sensitivity only after activation, ${ }^{16}$ interaction with CD95L might delete activated T cells in an allospecificimmune response in vitro while leaving non-activated naïve $T$ cells untouched.

Human CD95L exists in a membrane-bound (m-CD95L) and soluble (s-CD95L) form, which is generated from the membrane-bound form through cleavage at the cell surface by metalloproteinases. ${ }^{17}$ While membrane-bound CD95L efficiently mediates apoptosis in CD95 expressing cells by

\footnotetext{
${ }^{1}$ University Children's Hospital, Ulm, Germany; ${ }^{2}$ Skin Cancer Unit, German Cancer Research Center Heidelberg and University Hospital Mannheim, Mannheim, Germany and ${ }^{3}$ Department of Immunology, University of Ulm, Ulm, Germany

*Corresponding author: K-M Debatin, University Children's Hospital, Eythstr.24, 89070 Ulm, Germany. Tel.: + 49731 5002 7700; Fax: +49 731 5002 6681;

E-mail: klaus-michael.debatin@uniklinik-ulm.de

Keywords: human; T cells; antigen-presenting cells; apoptosis; immunomodulation; CD95L

Abbreviations: AICD, activation-induced cell death; APC, antigen-presenting cell; CD95L, CD95 ligand; CTL, cytotoxic T lymphocyte; EBV, Epstein-Barr virus; FITC, fluorescein isothiocyanate; LCL, lymphoblastoid cell line; m-CD95L, membrane-bound CD95L; MLR, mixed lymphocyte reaction; PBL, peripheral blood lymphocytes; PHA, phytohemagglutinin; PPD, peptide derivate of tuberculin; s-CD95L, soluble CD95L; TAP, transporter associated with antigen processing; TCR, T cell receptor Received 13.2.06; revised 15.5.06; accepted 19.6.06; Edited by PH Krammer; published online 11.8.06
} 
formation of trimers or higher molecular structures, s-CD95L can have pro- or antiapoptotic functions depending on the microenvironment. ${ }^{17,18} \mathrm{~s}-\mathrm{CD} 95 \mathrm{~L}$ is proapoptotic if oligomers are formed with the extracellular matrix but antiapoptotic by competing with the m-CD95L for binding to CD95 in the absence of oligomer formation. ${ }^{18}$ Cells transfected with $\mathrm{m}$ CD95L have been shown to efficiently induce cell death in T cell lines and lymphocytes. ${ }^{19,20}$ Thus, m-CD95L-expressing APC might be used in vitro to selectively deplete antigen-specific $T$ cells in solid organ transplantations to prevent graft rejection or to remove host-reactive $\mathrm{T}$ cells from allogeneic bone marrow transplants to minimize the risk of graft-versus-host disease.

To evaluate such a counterattack system for selective depletion of human $\mathrm{T}$ cells in vitro, we analyzed the modulation of an allospecific immune response in the presence of $\mathrm{m}$-CD95L-expressing APC. Long-term $\mathrm{T}$ cell cultures continuously stimulated with the alloantigen were used as a system to monitor the activation of antigen-specific $\mathrm{T}$ cells over an extended time period. Weekly stimulation of $\mathrm{HLA}-\mathrm{A} 1^{-} \mathrm{T}$ cells with APC coexpressing HLA-A1 and $m-C D 95 L$ induced the selective depletion of HLA-A1-specific $T$ cells while immunogenicity and cytotoxicity towards unrelated antigens were maintained.

\section{Results}

m-CD95L expressed on APC efficiently kills T cells. To obtain APC expressing membrane-bound CD95L (m-CD95L) we cultured the HLA-A1 expressing LCL C1R.A1 in the presence of $\alpha$-CD95mAb (up to $5 \mu \mathrm{g} / \mathrm{ml}$ ) for 8 weeks and subsequently performed limiting dilution to obtain CD95 negative clones (C1R.A1.CD95 ${ }^{-}$). C1R.A1.CD95 ${ }^{-}$cells were transfected with the cDNA coding for m-CD95L, which is expressed on the cell surface due to a mutation in the metalloproteinase cleavage site ${ }^{17}$ together with the puromycinresistance selection vector or the selection vector alone. $\mathrm{m}-\mathrm{CD} 95 \mathrm{~L}$ expressing single cell clones were obtained from bulk cultures by limiting dilution (C1R.A1.CD95L) and cells expressing the puromycin-resistant vector alone (C1R.A1.puro) were used as a control. Surface expression of CD95, CD95L, HLA-A1 and of costimulatory molecules CD80 and CD86 on the different cell lines is shown in Figure 1a. To confirm that $\mathrm{m}-\mathrm{CD} 95 \mathrm{~L}$ induces apoptosis, we cocultured C1R.A1.CD95L or C1R.A1.puro together with the human $T$ cell line Jurkat $\left(\mathrm{CD}^{+}, \mathrm{CD}^{+} 5^{+}\right)$for $3.5 \mathrm{~h}$ and analyzed cell death in the $\mathrm{CD}^{+}$population. While Jurkat cells cocultured with C1R.A1.puro revealed no signs of apoptosis, we detected $81 \%$ Annexin- $^{+}$Jurkat cells in the presence of C1R.A1.CD95L. Apoptosis induction by m-CD95L was extremely efficient compared to the agonistic anti-CD95 antibody (APO-1), which induced only $24 \%$ Annexin-Vpositivity at this early time point. Jurkat- $8^{-1-}$ cells, deficient for caspase-8 expression and insensitive for apoptosis induction via the CD95 pathway were resistant towards C1R.A1.CD95L and APO-1 treatment (Figure 1b). C1R.A1.CD95L cells also lysed activated $T$ cells such as Jurkat cells, PHA-activated human T cells or HLA-A1-specific $\mathrm{CTL}$ in a standard chromium release assay. While lysis of Jurkat cells started already after $4 \mathrm{~h}, \mathrm{CD}^{+}{ }^{+}$and $\mathrm{CD} 8^{+} \mathrm{PHA}$ blasts and HLA-A1-specific CTL or total HLA-A1-specific CTL
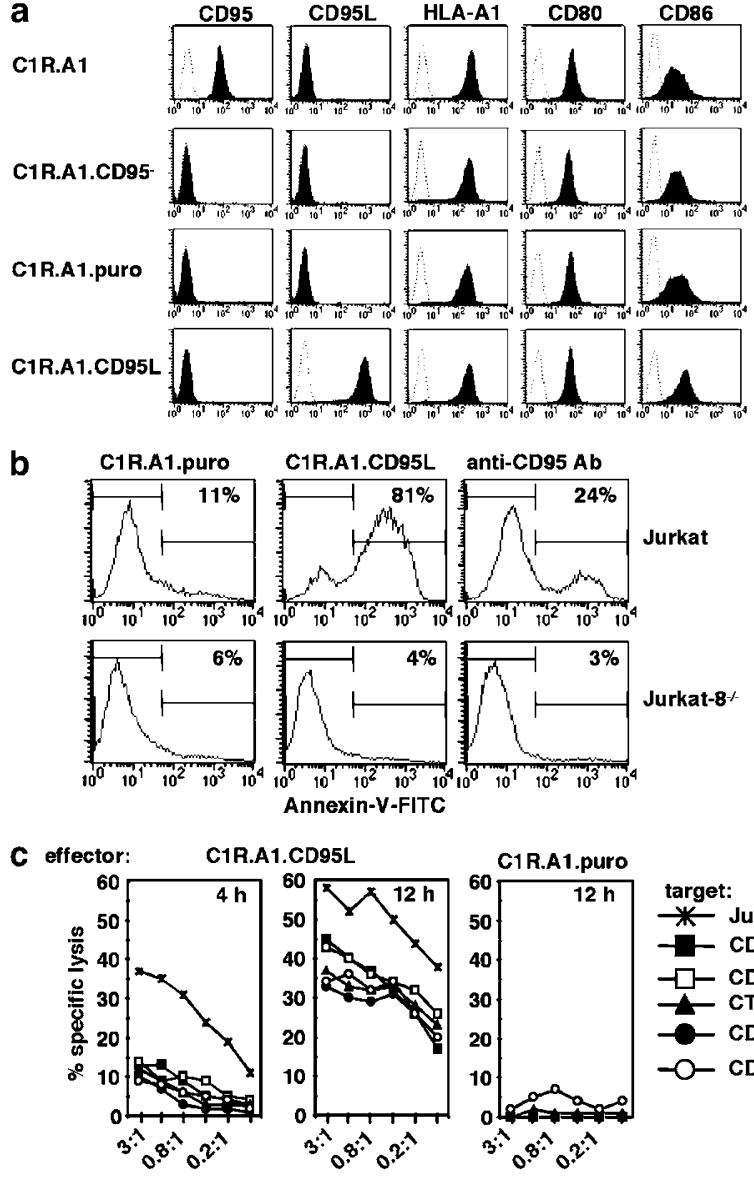

C1R.A1.puro

d

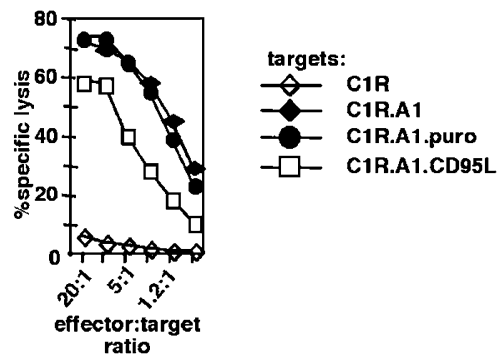

Figure $1 \mathrm{~m}-\mathrm{CD} 95 \mathrm{~L}$ induced apoptosis in $\mathrm{CD}^{+} 5^{+}$Jurkat cells and primary human T cells (a) C1R.A1 cells were made CD95 negative (C1R.A1.CD95 ${ }^{-}$) by culturing in anti-CD95 mAb (APO-1, $5 \mu \mathrm{g} / \mathrm{ml}$ ) containing medium over 8 weeks and subsequently cloned by limiting dilution. C1R.A1.CD95 ${ }^{-}$cell were then transfected with vectors carrying either the $\mathrm{m}-\mathrm{CD} 95 \mathrm{~L}$ gene and the puromycin resistance gene (C1R.A1.CD95L) or with the selection vector alone (C1R.A1.puro) and tested for HLA-A1, CD95, CD95L, CD80, and CD86 expression by FACS-analysis. (b) mCD95L induced apoptosis in CD95 ${ }^{+}$Jurkat cells: $\mathrm{CD} 3^{+}$Jurkat cells or Jurkat cells, deficient for caspase-8 (Jurkat-8 $8^{-1-}$ ) were coincubated with C1R.A1.CD95L and C1R.A1.puro cells at a ratio of $1: 1$ or APO- $1(1 \mu \mathrm{g} / \mathrm{ml})$. After $3.5 \mathrm{~h}$ cells were stained for $\mathrm{CD} 3$ and Annexin-V expression. Histograms show Annexin-V expression on gated $\mathrm{CD} 3^{+}$cells. (c) m-CD95L expressing cells induced lysis of $\mathrm{CD}^{2} 5^{+} \mathrm{T}$ cells: C1R.A1.CD95L or C1R.A1.puro cells were used as effector cells in a standard chromium release assay. Jurkat cells or $\mathrm{PHA}$ activated $\mathrm{CD} 4^{+}$and $\mathrm{CD} 8^{+} \mathrm{T}$ cells, HLA-A1-specific CTL bulk cultures (CTL, total) or isolated HLA-A1-specific CD4 ${ }^{+}$ or $\mathrm{CD} 8^{+} \mathrm{T}$ cells served as target cells. Specific lysis was determined after 4 and 12h. (d) C1R.A1.CD95L cells counterattack HLA-A1-specific CTL: in a cytotoxic $T$ cell assay chromium labeled target cells (C1R, C1R.A1, C1R.A1.CD95L, C1R.A1.puro) were incubated with HLA-A1-specific CTL. After $4 \mathrm{~h}$ specific lysis was calculated. All experiments were peformed at least three times with similar results 
cultures were lysed within 12h. C1R.A1.puro cells failed to induce cytotoxicity in any of these $T$ cell lines (Figure 1c). To test whether C1R.A1.CD95L cells counterattack and reduce cytotoxicity of HLA-A1-specific CTL, CTL were coincubated with the chromium labeled cell lines C1R.A1, C1R.A1.puro or C1R.A1.CD95L (Figure 1d). The HLA-A1 deficient line C1R served as a negative control. While C1R.A1 and C1R.A1.puro cells were efficiently lysed, cytotoxicity towards C1R.A1.CD95L was reduced, indicating that target cells expressing $\mathrm{m}-\mathrm{CD} 95 \mathrm{~L}$ counterattack cytotoxic effector cells. These data show that m-CD95L expressing LCL efficiently kill and counterattack CD95-expressing T cells in vitro.

Downmodulation of an alloimmune response by $\mathrm{m}$ CD95L expressing APC. To clarify whether m-CD95L expressing APC modulate an alloimmune response, HLAA1 ${ }^{-}$PBL were stimulated weekly with C1R.A1.CD95L or C1R.A1.puro (Figure 2a) and analyzed after each round of stimulation for total numbers and distribution of lymphocyte subpopulations. During the course of stimulation, absolute $T$ cell numbers continuously increased in cultures activated with C1R.A1.puro while the amount of $T$ cells activated in the presence of $\mathrm{m}-\mathrm{CD} 95 \mathrm{~L}$ only slightly increased during the first four rounds of stimulation declining thereafter (Figure $2 b$ ).
$\mathrm{CD}^{+} 6^{+}$cells representing neutrophils, macrophages and NK cells (Figure $2 \mathrm{e}$ and $\mathrm{j}$ ) and $\mathrm{CD}_{19}{ }^{+} \mathrm{B}$ cells (Figure $2 \mathrm{f}$ and $\mathrm{k}$ ) completely disappeared from C1R.A1.puro and C1R.A1.CD95L stimulated cultures. While $\mathrm{CD}^{+} \mathrm{T}$ cells constantly increased in number and proportion in C1R.A1.puro stimulated cultures, absolute numbers and percentage of $\mathrm{CD}^{+} \mathrm{T}$ cells in C1R.A1.CD95L activated cultures remained largely unchanged during the activation process (Figure $2 \mathrm{~d}$ and $\mathrm{i}$ ). In these cultures $\mathrm{CD} 4{ }^{+} \mathrm{T}$ cells remain the major $\mathrm{T}$ cell subpopulation throughout the stimulation process (Figure $2 \mathrm{c}$ and h). However, absolute numbers of CD4 ${ }^{+} \mathrm{T}$ cells also did not significantly increase during the stimulation process (Figure 2c). Additionally, expression of activation markers such as CD25, CD69 and CD45RO was diminished on $\mathrm{CD}^{+}$and $\mathrm{CD}^{+}{ }^{+} \mathrm{T}$ cells stimulated in the presence of $\mathrm{m}-\mathrm{CD} 95 \mathrm{~L}$ (data not shown). Thus, $\mathrm{m}-\mathrm{CD} 95 \mathrm{~L}$ expression on APC affected the response of $\mathrm{T}$ cells towards alloantigen.

m-CD95L-mediated depletion of HLA-A1-specific T cell responses does not affect reactivity towards third-party antigens. To test whether APC coexpressing $\mathrm{m}-\mathrm{CD} 95 \mathrm{~L}$ and allogeneic HLA class I molecules would selectively counterattack and delete alloantigen-specific $T$ cells without
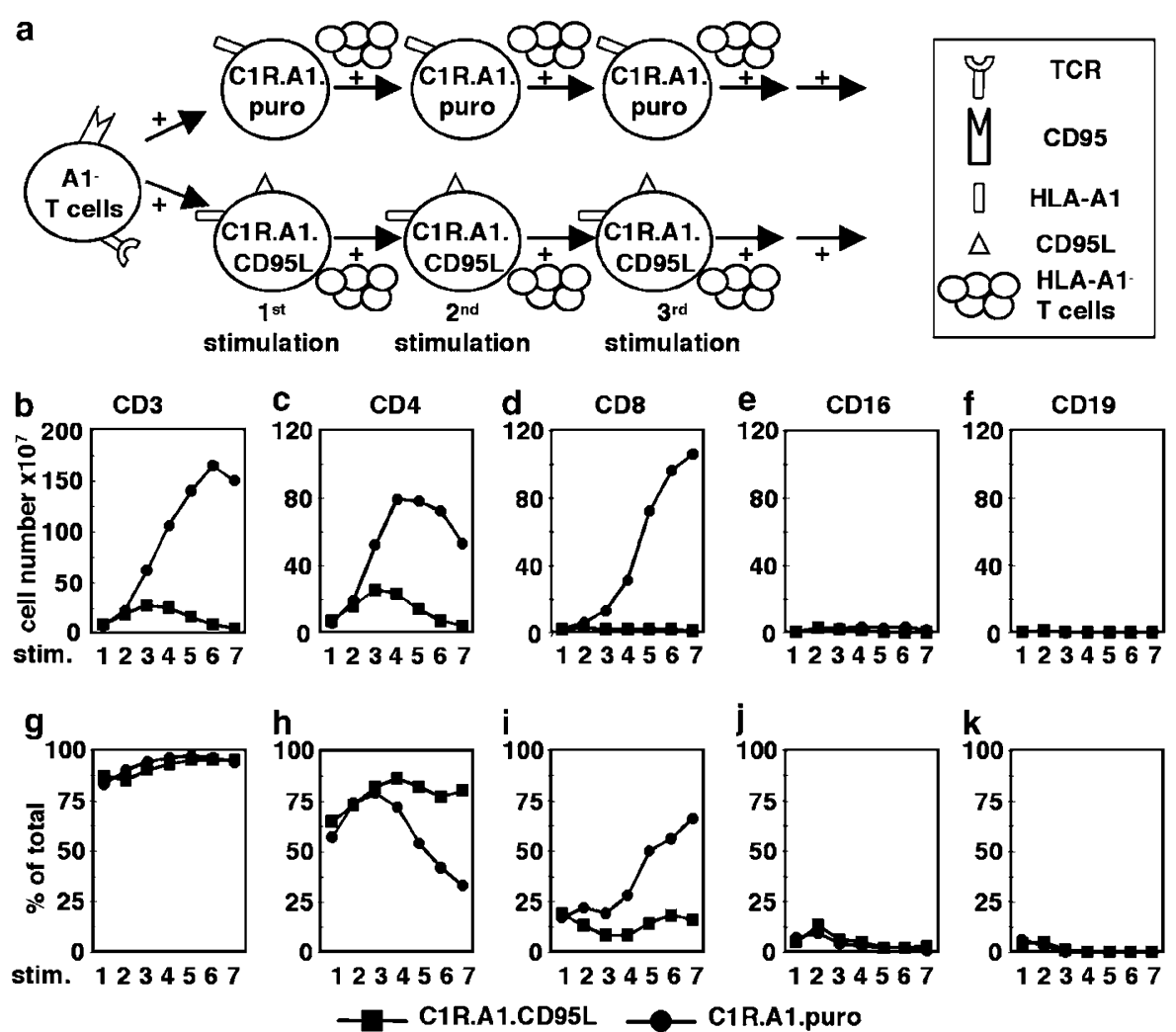

Figure $2 \mathrm{~m}$-CD95L expressing APC down modulate an alloimmune response. (a) Scheme of T cell activation by C1R.A1.puro and C1R.A1.CD95L. In brief, one half of $\mathrm{PBL}$ derived from healthy HLA-A1- donors was stimulated with C1R.A1.puro cells, while the other half was stimulated with C1R.A1.CD95L cells. After 1 week viable cells were separated and T cells, which were previously activated by C1R.A1.puro were stimulated a second time with C1R.A1.puro while T cells originally activated by C1R.A1.CD95L were restimulated by C1R.A1.CD95L (= second stimulation). Restimulation was carried out weekly at a T cell: stimulator rate of $10: 1$. (b-k) HLA-A1 negative T cells were weekly stimulated with C1R.A1.CD95L or C1R.A1.puro and after each round of stimulation absolute cell numbers (upper panel) and percentage of the different lymphocyte subsets (lower panel) was determined by FACS-analysis. Cells were stained for CD3 (b, g), CD4 (c, h), CD8 (d, i), CD16 (e, j) and CD19 (f, k) expression. Analysis was carried out with $T$ cells derived from four different donors with comparable results 
affecting $T$ cells specific for foreign antigens, we used C1R.A1.puro or C1R.A1.CD95L activated T cells as effector cells in MLR and compared them to the corresponding naïve $T$ cells to evaluate the effect of the stimulation protocol. Allogeneic PBL (allo PBL) pooled from five different HLAunrelated donors and C1R.A1 cells served as stimulators (Figure 3a). After two rounds of stimulation HLA-A1-specific proliferation was strongly reduced in C1R.A1.CD95L stimulated cultures compared to C1R.A1.puro activated cultures and did not exceed background stimulation after the fourth stimulation. While the HLA-A1-specific response was sequentially increased in C1R.A1.puro stimulated T cells compared to naïve $T$ cells, the response toward allo $P B L$ was detectable in naïve, C1R.A1.puro and C1R.A1.CD95L stimulated $\mathrm{T}$ cells. As the proportion of $\mathrm{CD}^{+}{ }^{+}$and $\mathrm{CD} 8^{+}$ $T$ cells was different in C1R.A1.puro and C1R.A1.CD95L activated cultures (as shown in Figure 2), we isolated CD4 ${ }^{+}$ and $\mathrm{CD}^{+}{ }^{+} \mathrm{T}$ cell subsets after the fifth round of stimulation and tested their proliferative capacity towards HLA-A1 or third-party alloantigen (Figure $3 \mathrm{~b}$ ). Consistent with the results obtained for bulk cultures, $\mathrm{CD}^{+}$and $\mathrm{CD}^{+} \mathrm{T}$ cells stimulated by C1R.A1.CD95L did not respond to HLA-A1-

a
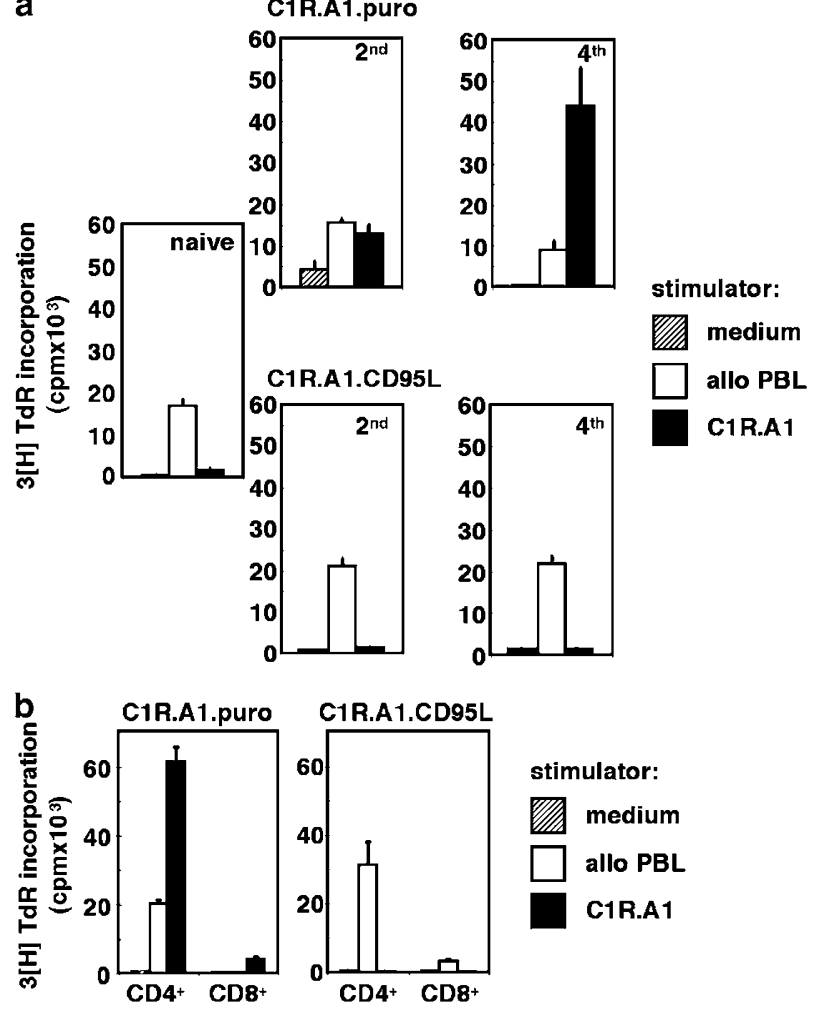

Figure 3 Selective depletion of HLA-A1-specific T cells by m-CD95L expressing APC does not impair reactivity towards third-party antigens. (a) HLA-A1 ${ }^{-} \mathrm{T}$ cells were weekly stimulated with C1R.A1.puro or C1R.A1.CD95L and used as effector cells in a MLR after the second and fourth round of stimulation and were compared to naïve T cells. Allo PBL or C1R.A1 cells served as stimulator cells. Proliferative response was detected after 6 days. (b) After the fifth round of stimulation $\mathrm{CD} 4^{+}$ and $\mathrm{CDB}^{+} \mathrm{T}$ cells were positively isolated by magnetic bead separation. Isolated $\mathrm{T}$ cells were activated in a MLR by allo PBL or C1R.A1 cells. Medium controls indicate background stimulation. Values represent the mean \pm S.D. of triplicates of one out of four separate experiments expressing cells but were activated by third-party alloantigens while C1R.A1.puro stimulated $T$ cells proliferated in response to HLA-A1.

$T$ cells cultured in the presence of $\mathrm{m}-\mathrm{CD} 95 \mathrm{~L}$ retain antiviral and antibacterial immunity. HLA-A2 and HLA-35 molecules, expressed on the LCL C1R.A1 in such a low amount that they are only detectable by HLA-A2- or -B35specific CTL but remain serologically undetectable ${ }^{21}$ might present Epstein-Barr-virus (EBV)-specific T cell epitopes. ${ }^{22}$ To further prove antigen-specificity of the depletion process, we analyzed whether autologous EBV-specific $T$ cell responses were retained. After depletion of HLA-A1specific $T$ cells by four rounds of stimulation with C1R.A1.CD95L, remaining $T$ cells were stimulated in a mixed lymphocyte reaction (MLR) with the autologous EBV line and C1R.A1 cells (Figure 4a). T cells activated four times with C1R.A1.puro or naïve $T$ cells from the same donor served as a control. T cells activated with C1R.A1.CD95L exhibited a strong proliferative response towards the autologous EBV line similar to naïve $T$ cells or $T$ cells activated with C1R.A1.puro. Complete depletion of HLA-A1specific $T$ cells was confirmed by unresponsiveness of $m-$ CD95L stimulated T cells towards C1R.A1.

To test whether $\mathrm{T}$ cell responses towards bacterial antigens such as PPD and tetanus toxid were maintained in $\mathrm{m}-\mathrm{CD} 95 \mathrm{~L}-$ activated $\mathrm{T}$ cell cultures, naive $\mathrm{CD} 4^{+} \mathrm{T}$ cells or $\mathrm{CD} 4^{+} \mathrm{T}$ cells cultured in the presence or absence of $\mathrm{m}-\mathrm{CD} 95 \mathrm{~L}$ after the fourth stimulation were isolated and cocultured with autologous APC in the presence of PPD and tetanus toxid (Figure 4b). Depletion of HLA-A1-specific T cells was confirmed by nonresponsiveness of C1R.A1.CD95L stimulated T cells toward C1R.A1 cells (data not shown). Proliferation against tetanus antigen was comparable in all $\mathrm{T}$ cell cultures. Proliferation upon PPD
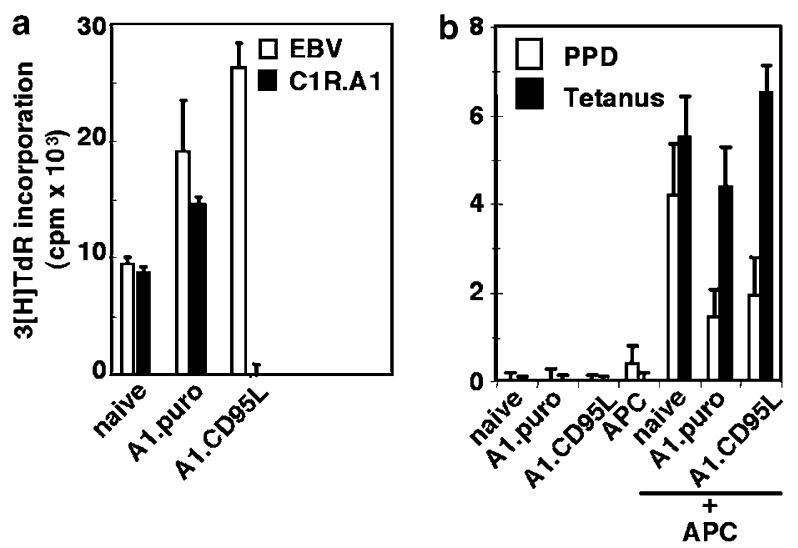

Figure 4 Antiviral and antibacterial responses are preserved in T cells depleted for HLA-A1 reactivity. HLA-A1 ${ }^{-} \mathrm{T}$ cells were cultured in the presence of C1R.A1.puro (A1.puro) or C1R.A1.CD95L (A1.CD95L) and used as effector cells after four rounds of stimulation. (a) T cells were activated by C1R.A1 cells or the autologous EBV cell line and the proliferative response was detected after 6 days. (b) $\mathrm{CD}^{+}{ }^{+} \mathrm{T}$ cells were isolated from the bulk cultures and coincubated with autologous naive $\mathrm{CD}^{-}$APC in the presence of PPD or tetanus toxid and the proliferative response was measured after 8 days. Values present the mean \pm S.D. of triplicates. Results are representative for three independent experiments with similar results 
stimulation was also detectable in all $\mathrm{T}$ cell cultures although slightly decreased in the C1R.A1.puro or C1R.A1.CD95Lstimulated cultures compared to naïve $\mathrm{T}$.

m-CD95L expressing APC prevent the activation of HLAA1-specific CTL. As stimulation with HLA-A1 expressing C1R.A1.CD95L cells prevent the activation of CD8 ${ }^{+} \mathrm{T}$ cells (see Figure 2), we examined whether the presence of $\mathrm{m}$ CD95L expressing APC could prevent the development of HLA-A1-specific CTL. Standard chromium release assays using T cells from C1R.A1.puro or C1R.A1.CD95L-stimulated cultures after different rounds of stimulation were used to test cytotoxicity towards the HLA-A1 expressing mouse mastocytoma cell line $\mathrm{P} 1 . \mathrm{A} 1^{23}$ and the parental line P1.HTR (P1) (Figure 5a). C1R.A1.puro stimulated T cells started to exhibit HLA-A1-specific cytotoxicity after three rounds of stimulation and the lytic capacity of $T$ cells increased with further stimulation. The presence of $\mathrm{m}-\mathrm{CD} 95 \mathrm{~L}$ on APC, however, prevented the activation of HLA-A1-specific CTL. To confirm that the lack of HLA-A1-specific cytotoxicity in the $\mathrm{m}$-CD95L-stimulated cultures was not due to the decreased number of $\mathrm{CD}^{+} \mathrm{T}$ cells compared to cultures stimulated by C1R.A1.puro (as shown in Figure 2), we isolated $\mathrm{CD}^{+}$and $\mathrm{CD}^{+} \mathrm{T}$ cells from both cultures after the fifth round of stimulation. While CD4 ${ }^{+} \mathrm{T}$ cells in both systems exhibited no cytotoxicity, only $\mathrm{CD}^{+} \mathrm{T}$ cells stimulated by C1R.A1.puro developed HLA-A1 reactivity (Figure $5 b$ ). Most probably, HLAA1-specific CTL recognized HLA-A1 determinants independent of the peptide presented, since the murine TAP-2 deficient RMA-S cells expressing HLA-A1 were also lysed, although less efficiently (Figure 5c). RMA-S.A1 expressed only class I molecules on the cell surface, which have been loaded with peptides in an TAP1/2-independent manner, thus completely differing in their peptide repertoire from TAP1/2 expressing P1.A1 cells. ${ }^{24}$
CTL established in the presence of $\mathrm{m}$-CD95L retain their cytotoxic capacity. As the presence of $m-C D 95 L$ and HLAA1 on APC inhibited the development of $\mathrm{CD}^{+}$HLA-A1specific CTL (Figure 5b), we examined whether nondepleted $\mathrm{T}$ cells still expressed mediators of $\mathrm{T}$ cell cytotoxicity. After five rounds of stimulation, $\mathrm{CD}^{+}{ }^{+}$and $\mathrm{CD} 8^{+} \mathrm{T}$ cells were isolated from cultures either activated by C1R.A1.puro or C1R.A1.CD95L and expression of perforin, granzyme B, CD95L and TRAIL was determined (Figure 6a). Granzyme B expression was present in the C1R.A1.CD95L stimulated $\mathrm{CD}^{+} \mathrm{T}$ cell cultures but more pronounced in the CD8 ${ }^{+}$ T cells activated with C1R.A1.puro. No difference in Granzyme $\mathrm{B}$ expression was detected in the $\mathrm{CD}^{+}{ }^{+} \mathrm{T}$ cell population. Perforin expression could also be detected; even in CD8 ${ }^{+}$ T cells of C1R.A1.CD95L stimulated cultures. CD8 ${ }^{+} \mathrm{T}$ cells activated in the presence or absence of $\mathrm{m}-\mathrm{CD} 95 \mathrm{~L}$ exhibited no difference in TRAIL and CD95L expression. While TRAIL expression was comparable in $\mathrm{CD} 4^{+} \mathrm{T}$ cells stimulated with C1R.A1.puro or C1R.A1.CD95L, CD95L expression was slightly increased in CD4 ${ }^{+} \mathrm{T}$ cells activated in the presence of C1R.A1.CD95L. Next, we analyzed whether cytotoxicity towards autologous EBV cell lines was maintained among nondepleted T cells. For four rounds of stimulation T cells were activated in the presence or absence of $\mathrm{m}-\mathrm{CD} 95 \mathrm{~L}$. At this time point, HLA-A1 cytotoxicity was achieved in C1R.A1.puro activated cultures and absent in C1R.A1.CD95L stimulated cultures (data not shown). Subsequently, both $\mathrm{T}$ cell cultures were stimulated with the autologous EBV cell line for two further rounds of stimulation (Figure $6 \mathrm{c}$ and $\mathrm{e}$ ) or with two further rounds of C1R.A1.puro (Figure 6d) or C1R.A1.CD95L (Figure 6b) cells and afterwards tested for EBV-specific cytotoxicity. While m-CD95L-activated cultures initially failed to lyse the autologous EBV cell line (Figure 6b), restimulation with the autologous EBV cell line induced EBV-specific cytotoxicity but no cytotoxicity towards HLA-A1 expressing targets (Figure 6c). In C1R.A1.puro-activated $\mathrm{T}$ cells
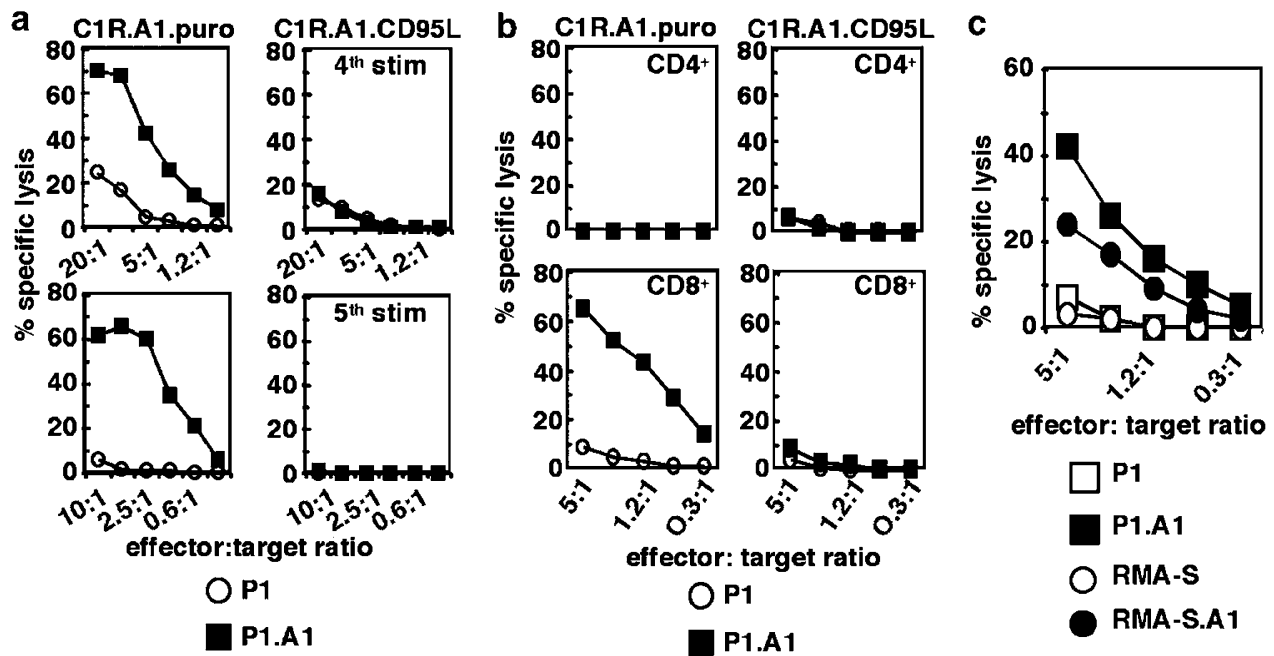

Figure 5 m-CD95L expressing APC prevent the activation of HLA-A1-specific CTL. HLA-A1- T cells were weekly stimulated with C1R.A1.puro or C1R.A1.CD95L cells and cytotoxic capacity was measured after 4 or 5 rounds of stimulation on HLA-A1 expressing target cells (P1.A1) and the HLA-A1 negative parental line (P1) in a standard

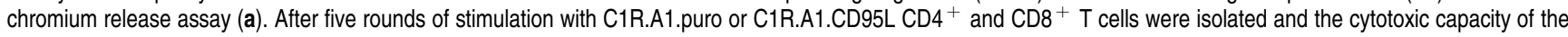
single subsets was tested on HLA-A1 expressing targets (b). HLA-A1-specific CTL after the fourth stimulation were incubated with P1, P1.A1, RMA-S and RMA-S.A1 cells in a standard chromium release assay and cytotoxicity was analyzed after $4 \mathrm{~h}(\mathbf{c})$. Data are representative for four independent experiments with similar results 

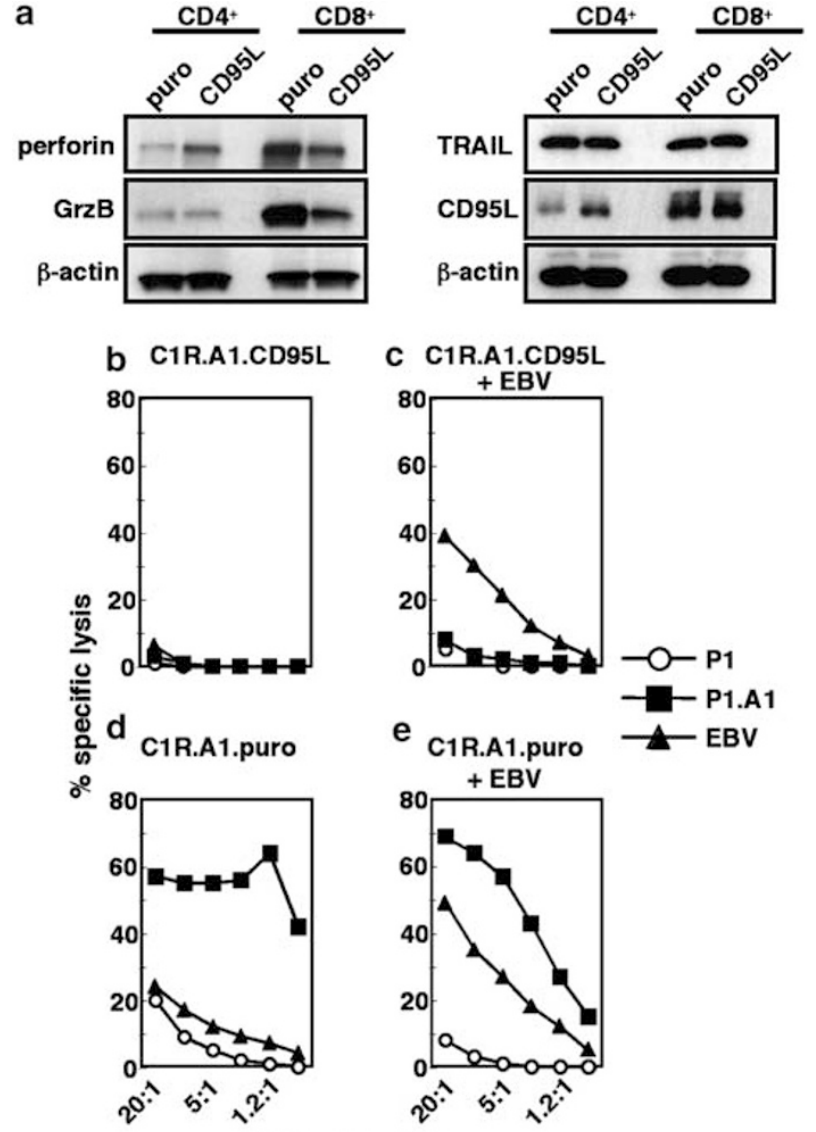

effector : target ratio

Figure 6 Depletion of HLA-A1-specific CTL by m-CD95L expressing APC does not impair cytotoxixity towards viral antigens. (a) HLA-A1 ${ }^{-}$negative $\mathrm{T}$ cells were activated by C1R.A1.puro (puro) or C1R.A1.CD95L (CD95L) and CD4 ${ }^{+}$or CD8 ${ }^{+}$ $T$ cell subsets were isolated after five rounds of stimulation and expression of perforin, granzyme B, CD95L and TRAIL was analyzed by Western Blot analysis. $\beta$-actin served as a loading control. (b) $\mathrm{HLA}-\mathrm{A} 1^{-} \mathrm{T}$ cells were activated by C1R.A1.puro or C1R.A1.CD95L for four rounds of stimulation until HLA-A1-specific cytotoxicity developed in the C1R.A1.puro $T$ cells and was absent in the C1R.A1.CD95L-stimulated T cells. Subsequently $T$ cells were restimulated twice with the autologous EBV cell line (C1R.A1.puro+EBV (e) or C1R.A1.CD95L + EBV (c)) or received two further rounds of stimulation with C1R.A1.puro (d) or C1R.A1.CD95L (b). Cytotoxicity was tested in a chromium release assay on P1, P1.A1 cells and the autologous EBV cell line (EBV)

EBV-cytotoxicity was detectable but only slightly increased compared to unspecific background lysis towards P1 (Figure 6d) but developed after restimulation with the autologous EBV cell line (Figure 6e). In summary, these results show that $m-C D 95 \mathrm{~L}$ expressing APC specifically inhibited the activation of HLA-A1-specific CTL but did not impair their non-HLA-A1-specific cytotoxic potential.

Coexpression of $\mathrm{m}$-CD95L and HLA-A1 alloantigen on the same APC is required to inhibit allogen-specific T cell responses. Next, we studied whether m-CD95Lmediated inhibition of allogen-specific $T$ cell activation requires coexpressing of HLA-A1 and $m-C D 95 L$ on the same APC. Therefore, we transfected $\mathrm{m}-\mathrm{CD} 95 \mathrm{~L}$ into the
HLA-A1 negative LCL C1R, rendered CD95-resistant by continuous culturing in anti-APO-1mAb similar to C1R.A1 cells (data not shown). C1R cells expressing m-CD95L (C1R.CD95L) were tested for apoptosis induction of $T$ cells and compared to C1R.A1.CD95L cells. C1R.A1.puro, C1R.CD95L and C1R.A1.CD95L cells were cocultured for $3.5 \mathrm{~h}$ with Jurkat cells or PHA-blasts and Annexin-V expression was analyzed on $\mathrm{CD}^{+}$cells (Figure $7 \mathrm{a}$ ). While C1R.A1.puro cells did not induce apoptosis, cell death induction of C1R.CD95L and C1R.A1.CD95L-treated T cells was comparable. To clarify whether $\mathrm{m}$-CD95L and HLA-A1 need to be coexpressed by the same APC, we stimulated HLA-A1 ${ }^{-} \mathrm{T}$ cells with C1R.A1.puro or C1R.A1.CD95L at an effector:stimulator ratio of $10: 1$. Simultaneously, HLA-A1 ${ }^{-} \mathrm{T}$ cells from the same donor were activated with C1R.CD95L cells and C1R.A1.puro at an effector:stimulator ratio of 10:1:1 (T cells:C1R.CD95L: C1R.A1.puro) (Figure $7 b$ ). Total $T$ cell numbers and distribution of $\mathrm{T}$ cell subsets were analyzed during the course of the stimulation (Figure 7c). In the presence of C1R.A1.CD95L, the allo-immune response was downmodulated. However, expression of $\mathrm{m}-\mathrm{CD} 95 \mathrm{~L}$ and HLA-A1 antigen on separate cells did not prevent $T$ cell expansion and outgrowth of $\mathrm{CD} 8^{+} \mathrm{T}$ cells. Only $\mathrm{T}$ cells stimulated by C1R.A1.CD95L coexpressing HLA-A1 and m-CD95L failed to exhibit HLA-A1-specific cytotoxicity (Figure 7e) while $T$ cells stimulated by a combination of C1R.CD95L and C1R.A1.puro developed into HLA-A1specific CTL (Figure 7f) with a cytolytic capacity similar to that induced in C1R.A1.puro activated T cells (Figure 7d). Although C1R.CD95L cells induced significant $T$ cell apoptosis in the stimulation cultures (data not shown) coexpression of the alloantigen and $\mathrm{m}-\mathrm{CD} 95 \mathrm{~L}$ on the same APC was required to prevent the activation of an alloantigenspecific $T$ cell response. Even increasing amounts of C1R.CD95L in the stimulation cultures up to effector: stimulator ratios of 10:1:5 ( $T$ cells:C1R.A1.puro.C1R. CD95L) could not inhibit $T$ cell expansion and activation of HLA-A1-specific CTL response (data not shown).

\section{Discussion}

CD95L expressed on $T$ cells mediates a dual function: effective destruction of $\mathrm{CD}^{+}{ }^{+}$target cells and induction of suicide or fratricide of activated $T$ cells at the termination phase of an immune response. ${ }^{4}$ As CD95L expression turns T cells into cytotoxic killer cells and simultaneously renders them susceptible for CD95-induced cell death, we questioned whether APC expressing CD95L could mediate antigenspecific $T$ cell depletion. The HLA-A1 expressing LCL C1R.A1.CD95 ${ }^{-}$was transfected with $\mathrm{m}-\mathrm{CD} 95 \mathrm{~L}$, which leads to stable surface expression of CD95L. m-CD95L-expressing APC efficiently induced apoptosis in CD95 expressing T cells. The presence of $m-C D 95 \mathrm{~L}$ in $\mathrm{T}$ cell stimulation cultures prevented T cell expansion, HLA-A1-specific $T$ cell responses and the activation of HLA-A1-specific cytotoxic T cells.

Although APC are the most potent inducers of $T$ cell activation, they may also be suitable for antigen-specific tolerance induction. In murine systems antigen-specific T cell deletion and tolerance induction in vitro and in vivo was 
achieved by CD95L-transfected APC. ${ }^{14,15}$ Also in the human system mature but not immature human DC retrovirally transduced with murine CD95L induced apoptosis induction in CD95-expressing $\mathrm{T}$ cells in vitro. ${ }^{25}$ However, to our knowledge, efficient alloantigen-specific depletion by

a

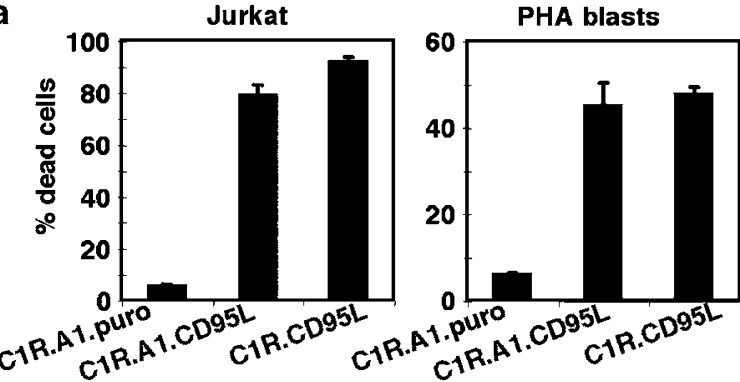

b

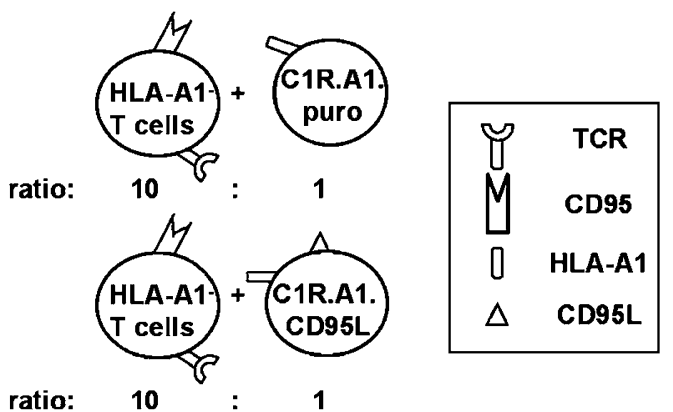

ratio:

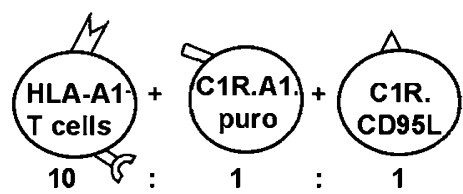

ratio:
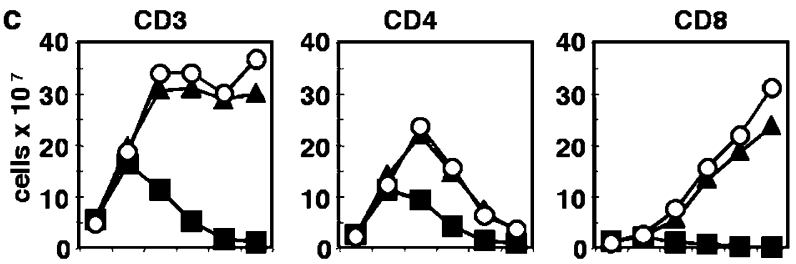

1. 2. 3. 4. 5. 6 .

1. 2. 3. 4. 5. 6 .
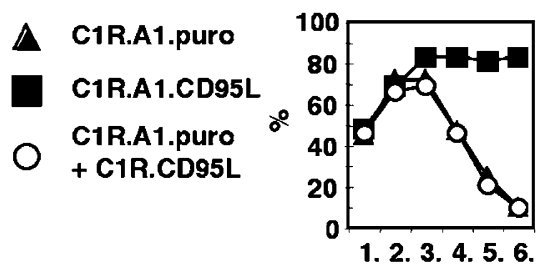

1. 2. 3. 4. 5. 6 .
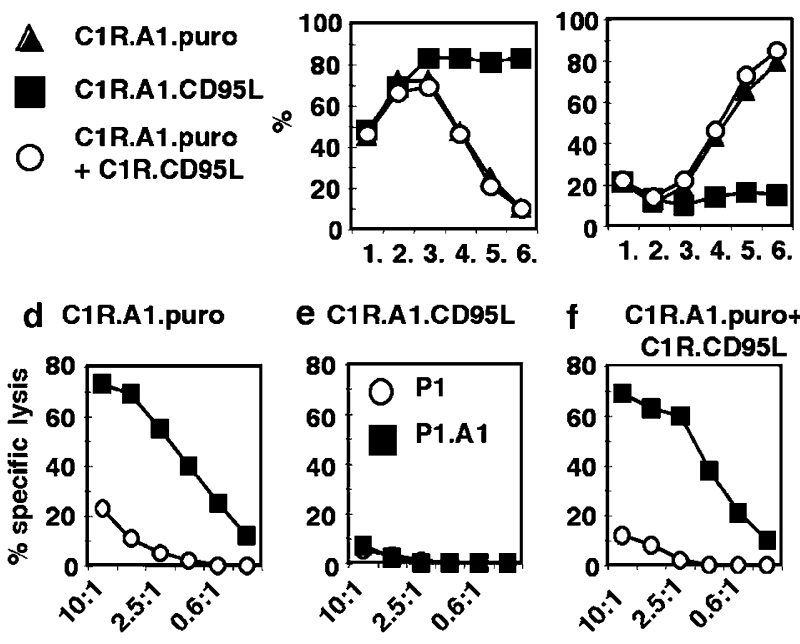

e C1R.A1.CD95L
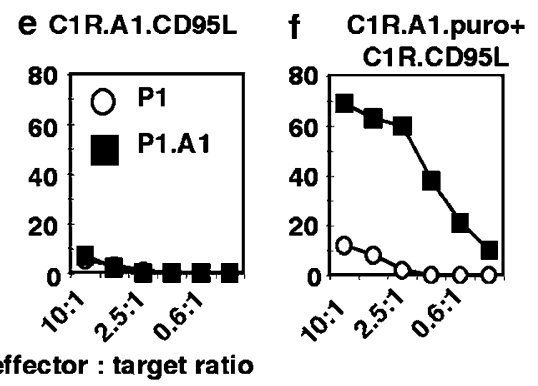

APC expressing $\mathrm{m}$-CD95L without impairment of immunity towards environmental antigens is shown here for the first time in the human system. Reports by Dulat et al. showed that CD95L transfected 293 human embryonic kidney cells induced modulation of an allo-immune response but failed to preserve reactivity of nondeleted $\mathrm{T}$ cell towards third-party antigens. ${ }^{26}$ Most likely, $\mathrm{T}$ cells stimulated by 293 cells are anergized, since 293 cells do not express costimulatory molecules needed for $\mathrm{T}$ cell activation.

While m-CD95L expressing APC efficiently induced selective $T$ cell depletion, the role of CD95L expressed on tumors to kill tumor infiltrating lymphocytes (counterattack) or on transplanted tissues to establish immunopriviliged sites is still controversial. $^{27}$ CD95L-expressing tumor cells have been reported to kill tumor-infiltrating lymphocytes, ${ }^{28,29}$ while other studies demonstrated that CD95L expression on tumors induced tumor rejection by inflammation in vivo. ${ }^{10,30}$ The controversial data indicate a discrepancy between the in vitro and in vivo action of CD95L. Although CD95L-expressing cells efficiently mediate cell death of CD95-sensitive T cells in vitro, the same cells are apparently not protected from rejection in vivo. ${ }^{10-12}$ As our model is operative under standardized in vitro culture conditions, $\mathrm{T}$ cell depletion is independent of environmental influences such as local cytokine pattern, vascularization and accessibility to cellular infiltration. The efficiency of our system might further depend on the fact that CD95L is used in a membrane-bound form. Noncleavable, membrane-bound CD95L was reported to induce death of CD95-expressing targets more efficiently than the soluble form. ${ }^{17,31}$ We observed that ex vivo isolated CD95 ${ }^{+}$T cells from peripheral blood were killed by $\mathrm{m}-\mathrm{CD} 95 \mathrm{~L}$ expressing APC (depending on the donor and the percentage of CD95 ${ }^{+}$ T cells $\sim 20-50 \%$ specific apoptosis) while CD95-sensitivity significantly increased during $T$ cell activation ( $\sim 80 \%$ specific apoptosis) (data not shown). However, the mechanism by which $\mathrm{m}-\mathrm{CD} 95 \mathrm{~L}$ expressing APC induce allogen-specific $\mathrm{T}$ cell depletion is not clear. We speculate that $\mathrm{m}-\mathrm{CD} 95 \mathrm{~L}$ expressing APC induce activation of the appropriate, naive $T$ cells followed by upregulation of CD95 and subsequent elimination of the T cell by CD95/CD95L interaction. However, we cannot exclude that the simultaneous triggering of the TCR and the CD95 receptor inhibits T cell activation and proliferation and induces anergy. Additionally, analysis of the

Figure 7 Coexpression of $m-C D 95 L$ and HLA-A1 on the same APC is required to prevent activation of HLA-A1-specific CTL. m-CD95L expressed on C1R (C1R.CD95L) and C1R.A1 (C1R.A1.CD95L) cells induces apoptosis in CD95 ${ }^{+}$ T cells with comparable efficiency: C1R.A1.puro, C1R.A1.CD95L and C1R.CD95L cells were coincubated for $3.5 \mathrm{~h}$ with $\mathrm{CD}^{+} 5^{+}$Jurkat $\mathrm{T}$ cells or PHA blasts and Annexin-V positivity was determined in the $\mathrm{CD}^{+}$population by FACS analysis (a). Scheme of T cell activation by different APC at different ratios (b). HLA-A1 ${ }^{-} \mathrm{PBL}$ were stimulated with C1R.A1.puro or C1R.A1.CD95L at an effector:stimulator ratio of $10: 1$ or with a mixture of C1R.CD95L + C1R.A1.puro at an effector:stimulator ratio of 10:1:1 (PBL:C1R.CD95L:C1R.A1.puro) and absolute T cell numbers and distribution of $T$ cell subsets were determined after each round of stimulation (c). HLA-A1-specific cytotoxicity of T cells stimulated for four times by C1R.A1.puro (d), C1R.A1.CD95L (e) or a mixture of C1R.CD95L and C1R.A1.puro (f) was tested on HLA-A1 expressing targets (P1.A1) and the HLA-A1 negative P1 cell line. Experiments were carried out with PBL from three different donors 
immunological synapse would further clarify the mechanism of $\mathrm{m}$-CD95L-mediated T cell depletion. As only $5-10 \%$ of the T cells are HLA-A1 specific at the beginning of the stimulation process and we are not able to distinguish those cells from the rest of the $\mathrm{T}$ cell population such analysis cannot be done in our system.

CD95 signaling and caspsase activation is not only linked to apoptosis induction but also to $\mathrm{T}$ cell activation and proliferation. $^{2}$ Along this line several reports indicated that TCR triggering protects from CD95-mediated apoptosis. ${ }^{32-34}$ In the murine system, naïve T cells were reported to die after TCR and CD95 ligation while memory $T$ cells were costimulated and induced to proliferate. ${ }^{35}$ However, all systems have in common that stimulation was achieved by monoclonal antibodies instead of APC coexpressing antigen, costimulatory molecules and CD95L on the cell surface. Even if CD95Lexpressing DC were used, apoptosis induction was always tested on unspecifically activated T cells for example by CD3/ CD28 activation and never on the corresponding antigenspecific T cell. ${ }^{25,36}$ Our results, however, clearly indicate that inhibition of $T$ cell responses by $m-C D 95 \mathrm{~L}$ cannot be prevented by TCR/antigen or CD28/B7 interaction at least if all stimuli are provided by the same APC. In accordance with this finding, elimination of antigen-specific $T$ cells was only achieved when CD95L and antigen were coexpressed on the same APC but not if both signals were delivered via separate APC.

As m-CD95L-expressing APC efficiently deplete the corresponding antigen-specific human $\mathrm{T}$ cells, they provide an attractive system for elimination of host-reactive $T$ cells in transplantation settings or autoimmune diseases in vitro. In vivo use of $\mathrm{m}-\mathrm{CD} 95 \mathrm{~L}$ expressing APC is not suitable since we can not predict the toxic effect of $\mathrm{m}-\mathrm{CD} 95 \mathrm{~L}$ expressing cells on CD95-expressing tissues. Although in several mouse models CD95L-expressing APC are successfully applied to eliminate antigen-specific $T$ cells, recent reports exhibit limited success of killer dendritic cells in preventing graft rejection ${ }^{37}$ and observed the development of pulmonary vasculitis ${ }^{38}$ after in vivo injection.

LCL used as APC are highly efficient in activation of $\mathrm{T}$ cells $^{39}$ and are available in unlimited numbers. However, death ligand expressing LCL might abrogate $T$ cell responses to minor antigens including tumor antigens restricted to the hematopoetic system in situations when antitumor responses are required for therapy. As we preserve an EBV-specific antigen-response after $T$ cell depletion, we speculate that tumor antigens restricted to the leukemic clone and presented in the context of self-HLA might theoretically be maintained. As the establishment of LCL and transfection with $\mathrm{m}-\mathrm{CD} 95 \mathrm{~L}$ requires time-consuming cell culture work for each individual patient, it will be worthwhile to test alternative strategies such as liposomes or microbeads coated with HLA/peptide ligands and $\mathrm{m}$-CD95L.

In conclusion, the present data provide strong evidence that an alloantigen-specific immune response can be abolished by $m-C D 95 L$ expressing APC without affecting reactivity towards third-party antigens. This approach might support the concept to use $\mathrm{m}$-CD95 $\mathrm{L}$ expressing APC as immunomodulators to achieve antigen-specific tolerance in transplantation settings and autoimmune diseases.

\section{Materials and Methods}

Plasmids and transfection. A CD95 $5^{-}$variant of the lymphoblastoid cell line (LCL) C1R.A1 ${ }^{23}$ termed C1R.A1.CD95 ${ }^{-}$was electroporated (220 V, $\left.950 \mu \mathrm{F}\right)$ with plasmid pBOSHFLD4 coding for human $\mathrm{m}$-CD95L, which carries a deletion at the metalloproteinase cleavage site ${ }^{17}$ and the selection vector pSV40-puro (generously provided by B. Baumann, Ulm, Germany) (C1R.A1.CD95L) or with pSV40-puro alone (C1R.A1.puro). Selection was carried out in $0.6 \mathrm{mg} / \mathrm{ml}$ puromycin (CLONTECH Laboratories, Heidelberg, Germany) containing medium. Single cell clones were obtained from bulk cultures by limiting dilution and tested for $\mathrm{m}-\mathrm{CD} 95 \mathrm{~L}-$ expression by flow cytometry.

Cell lines. All cell lines were grown in RPMl 1640 medium (GIBCO-BRL, Paisley, UK) supplemented with $10 \%$ heat-inactivated FCS (BioWhittacker, Verviers, Belgium), $2 \mathrm{mM}$ L-glutamine and $1 \mathrm{mM}$ sodium pyruvate at $37^{\circ} \mathrm{C}$ in a humidified atmosphere containing $7.5 \% \mathrm{CO}_{2}$

Generation of HLA-A1-specific T cells and PHA blasts. HLA-A1specific $T$ cells were established as previously described. ${ }^{40}$ In brief, one half of PBMC derived from healthy HLA-A $1^{-}$donors was stimulated with mitomycin Ctreated C1R.A1.puro cells, while the other half was stimulated with mitomycin Ctreated C1R.A1.CD95L cells and human rlL-2 (Biochrom KG) $(30 \mathrm{U} / \mathrm{ml})(=$ first stimulation). After 1 week viable cells were separated and T cells, which were previously activated by C1R.A1.puro were stimulated a second time with C1R.A1.puro while $T$ cells originally activated by C1R.A1.CD95L were restimulated by C1R.A1.CD95L (= second stimulation). Restimulation was carried out weekly at a T cell: stimulator rate of $10: 1$ in medium containing $30 \mathrm{U} /$ $\mathrm{ml}$ of rlL-2. To obtain PHA blasts PBMC were stimulated with $2.5 \mu \mathrm{g} / \mathrm{ml}$ PHA-P (Sigma, Taufkirchen, Germany) and rlL-2 (50 U/ml). After $24 \mathrm{~h}$ PHA was washed away and cells were cultured for 5 days in medium containing rlL-2 $(50 \mathrm{U} / \mathrm{ml})$.

Isolation of $\mathrm{T}$ cell subsets. To obtain $\mathrm{CD} 4^{+}$and $\mathrm{CD} 8^{+} \mathrm{T}$ cells, CTL or PHA-blasts were separated by the CD4 positive and CD8 positive isolation kit (Dynal, Hamburg, Germany). Purity of the populations ranged between 97 and $100 \%$.

Generation of EBV-transformed B-cell lines. PBMC $/ 2.5 \mathrm{ml}$ medium $\left(1 \times 10^{7}\right)$ were incubated with $2.5 \mathrm{ml}$ supernatant from the B95-8 EBV producer cell line at $37^{\circ} \mathrm{C}$. After $2 \mathrm{~h}, 5 \mathrm{ml}$ medium and $1 \mu \mathrm{g} / \mathrm{ml}$ Cyclosporine A (Sigma) was added. At 3 weeks after infection, cultures were expanded.

Measurement of apoptosis induction. Induction of apoptosis was determined by Annexin-V-FITC staining (Annexin-V-FITC kit, Bender Med Systems, Vienna, Austria) on a FACScan Cytometer (BD Biosciences, Heidelberg, Germany).

Chromium release assays. Target cells $\left(2 \times 10^{6}\right)$ were labeled with $100 \mu C_{i}$ $\mathrm{Na}^{51} \mathrm{CrO}_{4}$ (Amersham-Buchler, Braunschweig, Germany) for $1 \mathrm{~h}$. Increasing numbers of effector cells were titrated to $5 \times 10^{3}$ target cells and incubated for 4 or $12 \mathrm{~h}$ at $37^{\circ} \mathrm{C} .50 \mu \mathrm{l}$ of supernatant was assayed for ${ }^{51} \mathrm{Cr}$-release in a Top CountNXT ${ }^{\mathrm{TM}}$ counter (Perkin Elmer, Rodgau-Jügesheim, Germany). Maximum release was determined by incubation of target cells in $100 \mu \mathrm{l} 10 \%$ SDS and spontaneous release was determined by addition of medium. The percentage of specific release was calculated as \% specific release $=$ (experimental releasespontaneous release)/(maximum release-spontaneous release $) \times 100$. Assays were set up in triplicates and performed at day 6 after $\mathrm{T}$ cell stimulation.

Proliferation assays. T cells $\left(5 \times 10^{5}\right)$ were incubated with $5 \times 10^{5}$ mitomycin C-treated stimulator cells. After 5 days cells were pulsed with $1 \mu \mathrm{C}_{\mathrm{i}} /$ well [methyl- ${ }^{3} \mathrm{H}$ ]Thymidine (Amersham Biosciences, Freiburg, Germany) for $18 \mathrm{~h}$, harvested on an Inotech harvester (Wallac, Freiburg, Germany) and counted on a Top CountNXT ${ }^{\mathrm{TM}}$ counter. Proliferation of T cells incubated with medium alone was defined as background proliferation and subtracted from the data shown. To determine $\mathrm{T}$ cell proliferation towards bacterial antigens, $\mathrm{CD} 4{ }^{+} \mathrm{T}$ cells were purified from bulk cultures. T cells $\left(1 \times 10^{5}\right)$ were cultured together with $1 \times 10^{5}$ irradiated (60 Gy) autologous naïve CD4 ${ }^{-}$PBMC for 6 days in the presence of PPD $(1 \mu \mathrm{g} / \mathrm{ml}$, Chiron-Behring, Marburg, Germany) and Tetanus toxid ( $1 \mu \mathrm{g} / \mathrm{ml}$, Sigma) before radioactive label. CPM values representing wells containing no antigen were subtracted from the data shown. 
Flow cytometry. T cells $\left(5 \times 10^{5}\right)$ were stained with the following antibodies: CD3-FITC, CD4-PCP, CD8-PCP, CD80-PE, CD86-PE, NOK-1 (BD Biosciences), CD16-PE (Immunotech, Marseille, France), CD19-PE (Dako Cytomation, Hamburg, Germany), biotinylated anti-HLA-A1 (BmT Labor Produkte, Meerbusch, Germany) or CD95-FITC, goat anti-mouse IgG $(\mathrm{H}+\mathrm{L}) \mathrm{F}\left(\mathrm{ab}^{\prime}\right)_{2}$-FITC (Dianova, Hamburg, Germany), Streptavidin-FITC (Southern Biotechnology, Birmingham, USA). Analysis was performed on a FACScan cytometer (BD Biosciences).

Western blot analysis. For Western Blot analysis, T cells were lysed for 15 min at $4^{\circ} \mathrm{C}$ in lysis buffer (TRIS/HCl $30 \mathrm{mM}, \mathrm{pH} 7.5, \mathrm{NaCl} 150 \mathrm{mM}$, Triton X-100 $1 \%$, glycerol $10 \%$, PMSF $1 \mathrm{mM}$, DTT $1 \mu \mathrm{M}$ ) followed by high-speed centrifugation. Lysate $(20 \mu \mathrm{g})$ was separated on a 10-20\% gradient SDS page and electroblotted onto Hybond ECL nitrocellulose membrane (Amersham Biosciences). Membranes were blocked for $1 \mathrm{~h}$ in PBS supplemented with $5 \%$ milk powder and $0.1 \%$ Tween 20. Membranes were stained over night with the first $\mathrm{Ab}$, followed by 1 -h incubation with the HRP-conjugated second antibody and detection was carried out by enhanced chemo-luminescence (Amersham Biosciences). The following antibodies were used: granzyme $\mathrm{B}$ (Serotec, Duesseldorf, Germany), $\beta$-actin (Sigma), perforin (Kamiya Biomedical Company, Seattle, USA), CD95L (cl. G247) and TRAIL (BD Biosciences) and HRP-conjugated goat anti-mouse IgG (Santa Cruz Biotechnology Inc., Europe) and mouse anti-rat IgG Fc (Dianova).

Acknowledgements. We thank Dr S Nagata for providing us with plasmid pBOSHFLD4 coding for m-CD95L.

1. Rieux-Laucat F. Inherited and acquired death receptor defects in human Autoimmune Lymphoproliferative Syndrome. Curr Dir Autoimmun 2006; 9: 18-36.

2. Budd RC. Death receptors couple to both cell proliferation and apoptosis. J Clin Invest 2002; 109: 437-441.

3. Chen M, Wang YH, Wang Y, Huang L, Sandoval H, Liu YJ et al. Dendritic cell apoptosis in the maintenance of immune tolerance. Science 2006; 311: 1160-1164.

4. Siegel RM, Chan FK, Chun HJ, Lenardo MJ. The multifaceted role of Fas signaling in immune cell homeostasis and autoimmunity. Nat Immunol 2000; 1: 469-474.

5. Bellgrau D, Gold D, Selawry H, Moore J, Franzusoff A, Duke RC et al. A role for CD95 ligand in preventing graft rejection. Nature 1995; 377: 630-632.

6. Griffith TS, Brunner T, Fletcher SM, Green DR, Ferguson TA. Fas ligand-induced apoptosis as a mechanism of immune privilege. Science 1995; 270: 1189-1192.

7. Lau HT, Yu M, Fontana A, Stoeckert Jr CJ. Prevention of islet allograft rejection with engineered myoblasts expressing FasL in mice. Science 1996; 273: 109-112.

8. Kang SM, Schneider DB, Lin Z, Hanahan D, Dichek DA, Stock PG et al. Fas ligand expression in islets of Langerhans does not confer immune privilege and instead targets them for rapid destruction. Nat Med 1997; 3: 738-743.

9. O'Connell J, O'Sullivan GC, Collins JK, Shanahan F. The Fas counterattack: Fas-mediated T cell killing by colon cancer cells expressing Fas ligand. J Exp Med 1996; 184: 1075-1082.

10. Seino K, Kayagaki N, Okumura K, Yagita H. Antitumor effect of locally produced CD95 ligand. Nat Med 1997; 3: 165-170.

11. Behrens CK, Igney FH, Arnold B, Moller P, Krammer PH. CD95 ligand-expressing tumors are rejected in anti-tumor TCR transgenic perforin knockout mice. J Immunol 2001; 166 3240-3247.

12. Igney $\mathrm{FH}$, Behrens $\mathrm{CK}$, Krammer PH. CD95L mediates tumor counterattack in vitro but induces neutrophil-independent tumor rejection in vivo. Int J Cancer 2005; 113: 78-87.

13. Askenasy N, Yolcu ES, Yaniv I, Shirwan H. Induction of tolerance using Fas ligand: a double-edged immunomodulator. Blood 2005; 105: 1396-1404.

14. Matsue $\mathrm{H}$, Matsue $\mathrm{K}$, Walters $\mathrm{M}$, Okumura K, Yagita H, Takashima A. Induction of antigenspecific immunosuppression by CD95L cDNA-transfected 'killer' dendritic cells. Nat Med 1999; 5: 930-937.

15. Wolfe T, Asseman C, Hughes A, Matsue H, Takashima A, von Herrath MG. Reduction of antiviral CD8 lymphocytes in vivo with dendritic cells expressing Fas ligand-increased survival of viral (lymphocytic choriomeningitis virus) central nervous system infection $\mathrm{J}$ Immunol 2002; 169: 4867-4872.

16. Klas C, Debatin KM, Jonker RR, Krammer PH. Activation interferes with the APO-1 pathway in mature human T cells. Int Immunol 1993; 5: 625-630.

17. Tanaka M, Itai T, Adachi M, Nagata S. Downregulation of Fas ligand by shedding. Nat Med 1998: $4: 31-36$
18. Aoki K, Kurooka M, Chen JJ, Petryniak J, Nabel EG, Nabel GJ. Extracellular matrix interacts with soluble CD95L: retention and enhancement of cytotoxicity. Nat Immunol 2001; 2: 333-337.

19. Kang SM, Braat D, Schneider DB, O'Rourke RW, Lin Z, Ascher NL et al. A non-cleavable mutant of Fas ligand does not prevent neutrophilic destruction of islet transplants. Transplantation 2000; 69: 1813-1817.

20. Nafe C, Cao YJ, Quinones A, Dobberstein KU, Kramm CM, Rainov NG. Expression of mutant non-cleavable Fas ligand on retrovirus packaging cells causes apoptosis of immunocompetent cells and improves prodrug activation gene therapy in a malignan glioma model. Life Sci 2003; 73: 1847-1860.

21. Zemmour J, Little AM, Schendel DJ, Parham P. The HLA-A,B 'negative' mutant cell line C1R expresses a novel HLA-B35 allele, which also has a point mutation in the translation initiation codon. J Immunol 1992; 148: 1941-1948.

22. Rickinson AB, Moss DJ. Human cytotoxic T lymphocyte responses to Epstein-Barr virus infection. Annu Rev Immunol 1997; 15: 405-431.

23. Strauss G, Osen W, Debatin KM. Induction of apoptosis and modulation of activation and effector function in T cells by immunosuppressive drugs. Clin Exp Immunol 2002; 128: 255-266.

24. Smith KD, Lutz CT. Peptide-dependent expression of HLA-B7 on antigen processingdeficient T2 cells. J Immunol 1996; 156: 3755-3764.

25. Hoves S, Krause SW, Halbritter D, Zhang HG, Mountz JD, Scholmerich J et al. Mature but not immature Fas ligand (CD95L)-transduced human monocyte-derived dendritic cells are protected from Fas-mediated apoptosis and can be used as killer APC. J Immunol 2003 170: 5406-5413.

26. Dulat HJ, von Grumbkow C, Baars W, Schroder N, Wonigeit K, Schwinzer R. Down-regulation of human alloimmune responses by genetically engineered expression of CD95 ligand on stimulatory and target cells. Eur J Immunol 2001; 31 2217-2226.

27. Igney FH, Behrens CK, Krammer PH. Tumor counterattack - concept and reality. Eur J Immunol 2000; 30: 725-731.

28. Hahne M, Rimoldi D, Schroter M, Romero P, Schreier M, French LE et al. Melanoma cell expression of Fas(Apo-1/CD95) ligand: implications for tumor immune escape. Science 1996; 274: 1363-1366

29. Bennett MW, O'Connell J, O'Sullivan GC, Brady C, Roche D, Collins JK et al. The Fas counterattack in vivo: apoptotic depletion of tumor-infiltrating lymphocytes associated with Fas ligand expression by human esophageal carcinoma. J Immunol 1998; 160: 56695675 .

30. Miwa K, Asano M, Horai R, Iwakura Y, Nagata S, Suda T. Caspase 1-independent IL-1beta release and inflammation induced by the apoptosis inducer Fas ligand. Nat Med 1998; 4 1287-1292.

31. Suda $T$, Hashimoto $H$, Tanaka M, Ochi T, Nagata S. Membrane Fas ligand kills human peripheral blood T lymphocytes, and soluble Fas ligand blocks the killing. J Exp Med 1997; 186: 2045-2050.

32. Walker LS, McLeod JD, Boulougouris G, Patel YI, Ellwood CN, Hall ND et al. Lack of activation induced cell death in human T blasts despite CD95L up-regulation: protection from apoptosis by MEK signalling. Immunology 1999; 98: 569-575.

33. Kirchhoff S, Muller WW, Li-Weber M, Krammer PH. Up-regulation of c-FLIPshort and reduction of activation-induced cell death in CD28-costimulated human T cells. Eur $J$ Immunol 2000; 30: 2765-2774.

34. Holmstrom TH, Schmitz I, Soderstrom TS, Poukkula M, Johnson VL, Chow SC et al. MAPK/ERK signaling in activated $T$ cells inhibits CD95/Fas-mediated apoptosis downstream of DISC assembly. Embo J 2000; 19: 5418-5428.

35. Desbarats J, Wade T, Wade WF, Newell MK. Dichotomy between naive and memory CD4(+) T cell responses to Fas engagement. Proc Natl Acad Sci USA 1999; 96 8104-8109.

36. Lu L, Qian S, Hershberger PA, Rudert WA, Lynch DH, Thomson AW. Fas ligand (CD95L) and $B 7$ expression on dendritic cells provide counter-regulatory signals for $T$ cell survival and proliferation. J Immunol 1997; 158: 5676-5684.

37. Kusuhara M, Matsue $\mathrm{H}$. Limitations of CD95 ligand-transduced killer dendritic cells to prevent graft rejections. Exp Dermatol 2005; 14: 273-280.

38. Buonocore S, Flamand V, Claessen N, Heeringa P, Goldman M, Florquin S. Dendritic cells overexpressing Fas-ligand induce pulmonary vasculitis in mice. Clin Exp Immunol 2004; 137: 74-80.

39. Amrolia PJ, Muccioli-Casadei G, Yvon E, Huls H, Sili U, Wieder ED et al. Selective depletion of donor alloreactive $T$ cells without loss of antiviral or antileukemic responses. Blood 2003; 102: 2292-2299.

40. Strauss G, Knape I, Melzner I, Debatin KM. Constitutive caspase activation and impaired death-inducing signaling complex formation in CD95-resistant, long-term activated antigen-specific T cells. J Immunol 2003; 171: 1172-1182. 